\title{
Śmierć Judasza w Dz 1,18 jako przykład śmierci prześladowcy
}

Postać Judasza zaintrygowała teologów w związku z niedawno wydaną i medialnie rozpropagowaną Ewangeliq Judasza1. Zainteresowanie apokryficznym obrazem tego tragicznego apostoła nie oznacza, że o jego kanonicznym wizerunku powiedziano już wszystko. Sprawa tak podstawowa, jak jego śmierć, może wciąż jeszcze być przedmiotem zajmujących studiów. W tradycji kaznodziejskiej i ludowej przyjmuje się jako podstawową wersję z Mt 27,3-7, która już od dawna budzi wątpliwości egzegetów². Jest ona bowiem literacko rozwinięta i znacznie łatwiejsza do zrozumienia niż ta, którą przedstawiają Dz 1,18. Próbowano nieraz ignorować relację o śmierci Judasza z Dziejów Apostolskich $^{3}$ lub przedstawiać ją jako późniejszą ${ }^{4}$. W swoim komentarzu do

\footnotetext{
${ }^{1}$ Polski przekład i bibliografia: Ewangelia Judasza. Wstęp, tłumaczenie z koptyjskiego $i$ komentarz (SAC SN 8), tł. i red. W. Myszor, Katowice 2006. Reakcją na wypowiedzi autora tej publikacji była praca M. Starowieyskiego, Judasz historia, legenda, mity, Poznań 2006, 5-32.

2 J.R. Harris, Did Judas Really Commit Suicide?, AJTh 4 (1900) 490-513; P. Benoit, La mort de Judas, w: Synoptische Studien, Fs. A. Wikenhauser, München 1953, 1-19. Przykładem konkordystycznego podejścia nie biorącego pod uwagę autonomii tekstów jest zdanie: „Śmierć Judasza przedstawiona jest u Mateusza i w Dziejach jako samobójstwo, choć w nieco inny sposób" (M. Starowieyski, Judasz historia, legenda, mity, 16). Podobnie sprawę śmierci Judasza przedstawia C.S. Keener (Komentarz historyczno-kulturowy do Nowego Testamentu (PSB), Warszawa 2000, 238-239) czy D.H. Stern (Komentarz żydowski do Nowego Testamentu (PSB), Warszawa 2004, 365). Konkordystyczną tradycję egzegetyczną, biorącą początek u św. Augustyna i w starożytnych wersjach Dz 1,18 (OL i Wlg), przedstawia E. Dąbrowski, Dzieje Apostolskie. Wstęp - przekład z oryginału - komentarz (PŚNT 5), Poznań 1961, 231. Podobne ujęcie prezentuje opracowanie J.D.M. Derretta, Miscellanea: a pauline Pun and Judas' Punishment, ZNW 72 (1981) 131-133. Znacznie poprawniejsze ujęcie reprezentuje S. Stevan: „Według Mateusza, Judasz się powiesił, według Łukasza zginął śmiercią tragiczną" (tenże, Judasz. Misterium zdrady. Światto w ciemności, Kraków 2007, 63).

${ }^{3}$ M. Czajkowski, Uczniowie podczas męki Chrystusa, w: Męka Jezusa Chrystusa, red. F. Gryglewicz, 95-105, zwł. 101-102; C. Vidal Manzanares, Jezus $i$ Ewangelie. Mały słownik, Warszawa 2004, 91.

${ }^{4}$ M. Bocian, Leksykon postaci biblijnych, Kraków 1995, 295-300, zwł. 295.
} 
Dziejów Apostolskich Eugeniusz Dąbrowski podjął próbę obrony częściowej historyczności tekstu. Wyraził przekonanie, że Dz 1,18-19 nie należą do pierwotnego opowiadania5. Uważa, że te dwa wersety nie pasują do tego, co Piotr mówi o końcu Judasza w Dz 1,16-17.20. Wersety 18-19 miałyby być późniejsze i wprowadzać informacje częściowo uzgadniające relację Dziejów Apostolskich z tym, co mówi o Judaszu tradycja Markowo-Mateuszowa. Anachroniczna jest intencja Dąbrowskiego, by oddzielić to, co historycznie można przypisać Piotrowi od redaktorskiego wkładu w tekst mowy. Na przeciwnym biegunie można usytuować to, co o tragicznym apostole mówi John D. Crossan zakładający, iż tylko osoba Judasza jest historyczna, natomiast informacje, jakie przekazał na jego temat Nowy Testament, w tym także okoliczności jego śmierci, to wynik przetworzenia tradycji Starego Testamentu: ,nie ma żadnych historycznych na ten temat [Judasza]” - stwierdza amerykański badacz. „Tradycje chrześcijańskie [...] opisywały jego śmierć taką, jaką z pewnością musiała ona być: gwałtowną, straszną, zgodną z zapowiedziami Pisma"6. Według niego, doszukiwanie się jakiejkolwiek prawdy historycznej w relacji nowotestamentowej (a nie tylko, jak pisze, ewangelicznej) nie miałoby podstaw.

W niniejszym studium chcemy odpowiedzieć na pytanie o spójność teologiczną tego, co dzieło Łukaszowe mówi o Judaszu. Sądzimy bowiem, że jest to postać ukazana $\mathrm{z}$ pełną konsekwencją jako typowy prześladowca wierzących, który poniósł zasłużoną karę: zmarł haniebną i budzącą odrazę śmiercią. Chcemy też zapytać o wartość historyczną relacji Łukaszowej, by dać prawdziwie krytyczną odpowiedź na pytanie o możliwość ustalenia rodzaju śmierci, jaką umarł ten tragiczny apostoł ${ }^{7}$. Nie brak opinii, że wersja Łukaszowa powstała w całkowitej niezależności od historycznej albo mającej przynajmniej historyczny fundament tradycji Mateuszowej ${ }^{8}$. Klasyfikacja tej wersji jego śmierci, o której opowiadają Dzieje Apostolskie, jako chrześcijańskiego midraszu ${ }^{9}$ czy jako opowieści stereotypowej, charakterystycznej dla relacji

${ }^{5}$ E. Dąbrowski, Dzieje Apostolskie, 230.

6 J.D. Crossan, Kto zabit Jezusa? Korzenie antysemityzmu $w$ ewangelicznych relacjach o śmierci Jezusa, Warszawa 1998, 104.

7 A.D. Knox, The Death of Judas, JThS 25 (1923/24) 289-290; J. Herber, La mort de Judas, RHR 129 (1945) 47-565; R. Silva, ¿Cómo murió Judas, el traidor?, CB 24 (1967) 35-40; C.S. Bartnik, Judas l'Iscariote, historie et théologie, CT 19 (1980) 57-69; H. Stein-Schneider, À la recherché du Judas historique, ETR 60 (1985) 403-424; W. Klassen, Judas Iscariot, w: ABD III, 1090-1096; R.E. Brown, The Death of the Messiah. From Gethsemane to the Grave: Commentary on the Passion Narrative in the Four Gospels, t. 2, New York 1994, 1405-1410.

${ }^{8}$ R.E. Brown, The Death of Messiah, 1405-1406.

9 J. Dupont, La destinée de Judas prophetisée par David, Actes 1:16-20, CBQ 23 (1961) 41-51; F. Manns, Un midrash chrétien; le récit de la mort de Judas, RevSR 54 (1980) 197-203. 
o karze Boskiej za prześladowania prawdziwej wiary i jej wyznawców ${ }^{10}$, zdają się podważać historyczną wartość Dz 1,16-23. Należy jednak spojrzeć na stereotyp literacki nie tyle jako na przeciwieństwo informacji historycznej, ale raczej jako na jej specyficzną, gatunkowo zakodowaną formę.

\section{Dz 1,16-20: analiza egzegetyczna}

O zdradzie i śmierci Judasza opowiada w Dziejach Apostolskich Piotr, który zwraca się w swoim przemówieniu do szerokiego grona uczniów, szacowanego na 120 osób (Dz 1,15). Jest to grupa stosunkowo liczna, ale zamknięta. Mowa Piotra (Dz 1,16-22), pierwsza w księdze, ma szczególną rolę ${ }^{11}$. Akcja opowiadania, po wniebowstąpieniu Jezusa, jest bowiem w impasie. Mianowicie - po powrocie z Góry Oliwnej w pomieszczeniu na górze pozostają w zamknięciu: 11 apostołów, kobiety i bracia Jezusa (Dz 1,13-14). Lista apostołów jest dosyć podobna do tej, jaką znajdujemy w Łk 6,14-16. Występują na niej te same imiona, poza opuszczonym w Dz 1,14 z powodów oczywistych imieniem Judasza Iskarioty. W pozostałych wyliczeniach imion apostołów zamyka ono zawsze listę (Mk 3,19; Mt 10,4; Łk 6,16), podobnie jak imię Piotra ją otwiera (Mk 3,16; Mt 10,2; Łk 6,14). Między listami apostołów w Łk i Dz można jeszcze dostrzec znaczącą różnicę konstrukcyjną. O ile lista w Łk 6,14-16 jest oparta na parach braci (Szymon Piotr i Andrzej, Jakub i Jan), to Dz 1,13-14 opierają się na nowym kryterium: na pierwszych dwóch miejscach sytuują dwie postacie, które pojawiają się w tej księdze razem jako przywódcy Kościoła w Jerozolimie Piotra i Jana (3,1-11; 4,13.19; 8,14). Postać Jana Apostoła występuje w Dz tylko w parze z Piotrem. Wyjątkiem jest Dz 12,2, ale tu jest on wspomniany wyłącznie ze względu na Jakuba, swego brata. Jan nie jest więc w Dziejach postacią samodzielną. Stanowi raczej tło dla przywódcy grona apostołów, gwarancję kolegialności jego posługiwania. Piotr jest natomiast mówcą, który zabiera głos wobec różnych grup: wierzących, adresatów przepowiadania kerygmatycznego, przywódców religijnych judaizmu. Kolegium Dwunastu w Dz 1,13 ma więc kształt dostosowany do nowej sytuacji Kościoła, jest jednak niekompletne. Piotr sprawuje w nim rolę przywódcy i reprezentanta. Mowa Piotra zawiera podstawowe założenia, które mają posłużyć do uzupełnienia niekompletnego kolegium. Można podzielić ją na dwie zasadnicze części: przedstawienie końca życia Judasza i zastąpienie go przez inną osobę jako zdarzenia przewidziane

\footnotetext{
${ }^{10}$ P. Benoit, Death of Judas, 194; R.E. Brown, The Death of Messiah, 1409, przyp. 28.

${ }^{11}$ E. Dąbrowski, Dzieje Apostolskie, 526-533.
} 
w planie Bożym (Dz 1,16-20) oraz wskazanie procedury wyboru nowego członka (Dz 1,21-22). Nasza uwaga skupia się na pierwszej części. Jest ona znacznie obszerniejsza od drugiej i pełni rolę argumentacji, która ma nadać krokom wskazanym przez Piotra charakter prawomocny i oparty na Boskim autorytecie.

Tekst interesującej nas perykopy zawiera więc początek całej mowy. Kończą zaś perykopę dwa cytaty z Księgi Psalmów, które pełnią rolę uzasadnienia dla działań zaleconych w drugiej części mowy. Można więc powiedzieć, że perykopa ta nie jest w pełni samodzielna kompozycyjnie, w całości mowy stanowi jednak wyodrębnioną jednostkę. Śmierć Judasza nie jest jednak zasadniczym przedmiotem wystąpienia Piotra, mimo że poświęca się jej znaczącą ilość tekstu. To wydarzenie ma być nie tyle opowiedziane, ile raczej naświetlone tak, aby ukazać postępowanie apostołów mające na celu dopełnienie i, w pewnym sensie, skorygowanie decyzji podjętej przez Jezusa.

Teksty aleksandryjski i zachodni w omawianym zakresie nie różnią się znacznie $^{12}$. Pierwszy z nich jest niewiele krótszy i wydaje się pierwotniejszy. Przyjmujemy go zatem za podstawę studium egzegetycznego.

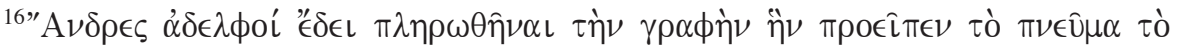

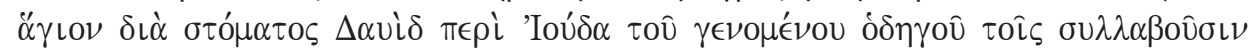

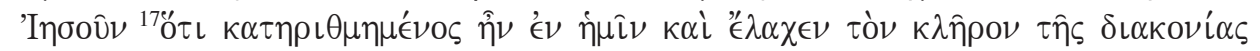

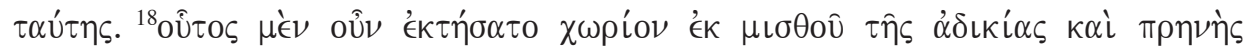

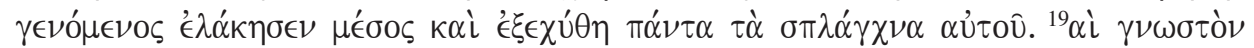

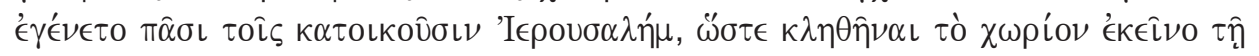

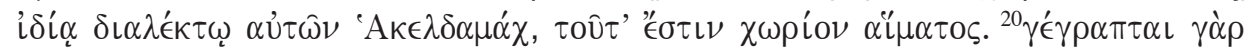

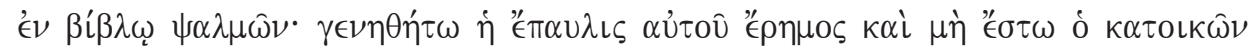

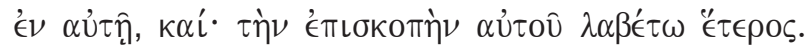

${ }^{16}$ Mężowie bracia, musiało wypełnić się pismo, które przepowiedział Duch Święty poprzez usta Dawida o Judaszu, który stał się przewodnikiem tych, którzy pojmali Jezusa, ${ }^{17}$ jako że zaliczany byt do nas $i$ otrzymat dziedzictwo tej postugi. ${ }^{18}$ Ten więc nabyt rolę z zapłaty nieprawości, stał się głowq naprzód na środku, rozerwat się i rozlały się wszystkie jego wnętrzności. ${ }^{19}$ I stało się to znane wszystkim mieszkańcom Jeruzalem, dlatego rola ta została nazwana Hakeldamach, to jest Rola Krwi. ${ }^{20}$ Zostało bowiem napisane w Księdze Psalmów: „, niech się stanie jego domostwo pustkowiem i niech nie będzie $w$ nim mieszkańców” $i$ „[sprawowany przez] niego nadzór niech weźmie inny".

12 E. Dąbrowski, Dzieje Apostolskie, 115-127; M.-É. Boismard - A. Lamouille, Texte occidental des Actes des Apôtres, t. 1-2, Paris 1984; E. Delebecque, Les deux Actes des Apôtres (EtB), Paris 1986; W.A. Strange, The Problem of the Text of Acts (SNTS.MS 71), Cambridge 1992; W. Rakocy, „Będziecie moimi świadkami...” (Dz 1,8), w: Dzieje Apostolskie, Listy św. Pawła (WMWKB 9), red. J. Frankowski - S. Mędala, Warszawa 1997, 13-81, zwł. 24. 
Początek mowy jest bardzo charakterystyczny dla stylu Dziejów Apostolskich,

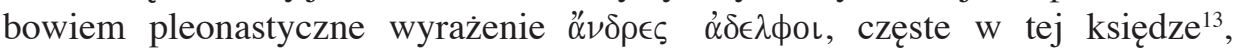
w Nowym Testamencie poza nią nie występuje, a w Septuagincie pojawia się tylko raz (4 Mch 8,19). Jest więc ono cechą stylu redaktora Dz. Następująca

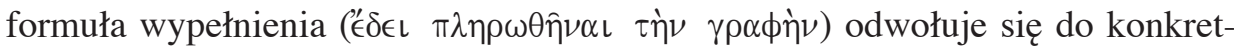
nego tekstu, podobnie jak Dz 2,16.25.29.34; 3,22; 4,25; 7,32.35.37; 28,25. Większość tak wprowadzanych cytatów z Starego Testamentu pojawia się więc w pierwszej części Dz, która mówi o Piotrze. Są to przeważnie odsyłacze do postaci Dawida i do Księgi Psalmów. Także ten element możemy uznać za typowy dla stylu redaktorskiego autora Dziejów Apostolskich.

O losie Judasza jako przewidzianym przez Pismo wspomina jeszcze J 17,12. R.E. Brown potwierdza, że choć w wersecie tym żaden tekst nie jest wspomniany wprost, chodzi o odniesienie do Starego Testamentu ${ }^{14}$. Wypełnienie słów Ps 41,9 w działaniach Judasza wspomniane jest wprost w J 13,18. W Mt 26,23; Mk 14,20; Łk 22,21 znajdujemy aluzję do tego samego tekstu z Księgi Psalmów, ale bez formuły wypełnienia. Teksty kanoniczne powtarzają więc ideę, że zdrada Judasza była wpisana w Boży plan zbawienia na równi $\mathrm{z}$ innymi wydarzeniami Męki ${ }^{15}$. Należy jednak zawsze mieć na uwadze, że teksty te nie mają wydźwięku deterministycznego ${ }^{16}$. Można przypuszczać, że nie był im obcy cel apologetyczny: ukazanie apostazji jako problemu obecnego w Kościele zawsze, ale niewywołującego fundamentalnego kryzysu ${ }^{17}$. Ujęcie to odpowiada w pełni temu, co znajdujemy w opowiadaniu Dz 1,16-20.

Werset zawiera wyraźną aktualizację cytatu z Ps, który ma się pojawić dopiero w Dz 1,20. Od początku mowy aktualizacja jest traktowana jako zasadnicza metoda interpretacji biblijnej. Taki wyraźnie egzegetyczny charakter mowy Piotra jest charakterystyczny dla jego mów w Dz, natomiast użyty typ egzegezy przypomina praktyki interpretacyjne wspólnoty w Qumran ${ }^{18}$. Słowa wypowiedziane przez Dawida są efektem działania Ducha Świętego, ,przepowiadającego” wydarzenia, o których hagiograf (w tym przypadku Dawid, któremu przypisana

\footnotetext{
${ }^{13}$ Dz 1,16; 2,29.37; 7,2.26; 13,15.26.38; 15,7.13; 22,1; 23,1; 28, 17.

${ }^{14}$ R.E. Brown, Giovanni. Commento al Vangelo spirituale, Assisi 1991³, 926-927.

15 W. Hryniewicz, Dramat nadziei zbawienia. Medytacje eschatologiczne, Warszawa 1996, 109.

${ }^{16}$ A. Paciorek, Ewangelia umiłowanego ucznia, Lublin 2000, 372.

${ }^{17}$ L. Stachowiak, Ewangelia według św. Jana. Wstęp - przekład z oryginału - komentarz (PŚNT 4), Poznań - Warszawa 1971, 345.

${ }^{18}$ L.T. Johnson, The Acts of the Apostles (SP 5), Collegeville 1992, 39. Por. F.F. Bruce, Biblical Exegesis in the Qumran Texts, London 1960, 16-18; K.H. Schekle, La Comunità di Qumran e la Chiesa del Nuovo Testamento, Roma 1970, 107-112; G.J. Brook, Exegesis at Qumran: 4QFlorilegium in Its Jewish Context (JSOTSup 29), Sheffield 1985; A. Tronina, Biblia w Qumran (BZ.TNT 8), Kraków 2001, 112-118.
} 
jest Księga Psalmów) nie musi wiedzieć. Sens Pism objawia się wraz z rozwojem wydarzeń, jak w komentarzu typu peszer ${ }^{19}$.

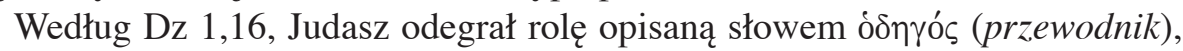
które znajduje się w miejscu, gdzie spodziewalibyśmy się raczej imiesłowu $\pi \alpha \rho \hat{\alpha}$

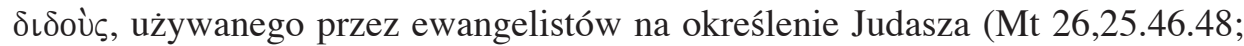
$27,3 ;$ Mk 14,42.44; J 18,2.5; 21,20 $)^{20}$. Łukasz nie używa tego określenia ${ }^{21}$, a rolę

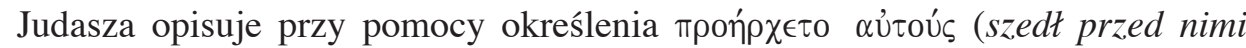
[tłumem], Dz 22,47) 22. Jest to sformułowanie, które dotyczy tylko i wyłącznie relacji przestrzennej między Judaszem a grupą mającą aresztować Jezusa. Trudno się w tym dopatrywać podkreślenia przywódczej roli Judasza ${ }^{23}$. Idzie on „z przodu”, co służy do zdefiniowania charakteru tłumu, który dokonuje pierwszego aktu agresji wobec Jezusa. O Judaszu już wcześniej Łukasz powiedział, że wstąpił w niego szatan $(22,3)^{24}$, a później włoży w usta Jezusa słowa o panowaniu ciemności (22,53), które zaczyna się z aresztowaniem Jezusa. Można więc powiedzieć, że istniał zamysł Łukaszowy, by odpowiedzialność z osoby Judasza przenieść na czynnik nadprzyrodzony, marginalizując podmiotowość tragicznego apostoła, a czyniąc z niego agenta szatana ${ }^{25}$.

19 G.J. Brook, Peszer, w: Słownik hermeneutyki biblijnej (PSB), red. R.J. Coggins J.L. Houlen, Warszawa 2005, 664-665; S. Jędrzejewski, Peszer jako metoda egzegetyczna, Seminare 24 (2007) 111-126.

${ }^{20}$ W. Bösen, Ostatni dzień Jezusa z Nazaretu, Wrocław i in. 2002, 157-158; J.B. Szlaga, Co Pismo św. mówi o zdradzie Judasza?, Ethos 17 (2004) 89-98; H. Ordon, Anatomia Judaszowej zdrady; tamże, 98-110.

${ }^{21}$ W Dz pojawia się ono tylko w 22,4 na określenie Pawła w okresie jego zaangażowania w prześladowanie chrześcijan.

${ }^{22}$ Łk używa czasownika $\pi \alpha \rho \alpha \delta i ́ \delta \omega \mu \iota$ w odniesieniu do Judasza $(22,4.6 .48$, por. 22,21n). Czyni to jednak znacznie rzadziej niż inni ewangeliści, dla których jest to jedyny czasownik określający czynność Judasza. Użycie to jest wynikiem niezróżnicowanego charakteru wcześniejszej tradycji, którą Łk próbuje ubogacić.

${ }^{23}$ Co sugeruje W. Klassen, Judas Iscariot, 1094n. Tym śladem idą komentarze popularne (np. R. Karris, Ewangelia według św. Łukasza, w: Katolicki komentarz biblijny (PSB), red. R.E. Brown - J.A. Fitzmyer - R.E. Murphy, Warszawa 2001, 1034-1107, zwł. 1100) i przekłady. Inni autorzy są znacznie ostrożniejsi. J.A. Fitzmyer (The Gospel According Luke [AB 28A], t. 2, New York i in. 1985, 1450) mówi tylko o zintensyfikowaniu roli Judasza w Łk 22,47 względem wcześniejszej tradycji. D. Senior (La passione di Gesù nel Vangelo di Luca, Milano 1992, 89) mówi o „delikatnym podkreśleniu”. R. Bartnicki (Ewangeliczne opisy Męki w aspekcie literackim, teologicznym i kerygmatycznym, w: Grzech - odkupienie - miłość [SzB 3], Warszawa 1983, 67-207, zwł. 156) pisze wręcz, że Łukasz pomniejsza rolę Judasza w aresztowaniu Jezusa.

${ }^{24} \mathrm{O}$ oryginalności tej informacji w Łk zob. W. Linke, Semicki idiom w J 13,2, w: Żyjemy dla Pana, Fs. E.J. Jezierska, red. M. Rosik, Wrocław 2005, 323-332, zwł. 323-324. J.A. Fitzmyer (The Gospel According to Luke, 1374) rozwija tę myśl, pokazując, jak jest wpisana w plan całej trzeciej Ewangelii.

${ }^{25}$ Pomimo popularnego charakteru swego opracowania, rzecz ujmuje trafnie D. Gooding 


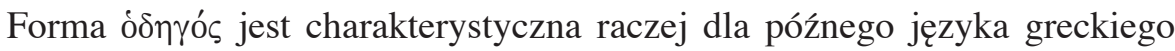
(hellenistycznej koine): Polibiusza ${ }^{26}$, Plutarcha ${ }^{27}$ czy Pauzaniasza ${ }^{28}$. Słowo to występuje w Septuagincie na określenie przewodnika oddziałów wojskowych (1 Mch 4,2; 2 Mch 5,15), przywódców politycznych (Ezd 8,1 tylko w wersji greckiej) oraz Boga, który sam (Mdr 7,15) lub przez cudowny znak (Mdr 18,3) kieruje swym ludem. W Nowym Testamencie tego rzeczownika używają Mt $(15,14$ z czasownikiem z tej samej rodziny słowotwórczej; 23,16.23) zawsze z przymiotnikiem ,ślepy”, Paweł (Rz 2,19) w odniesieniu do Żyda, który jest przekonany o swej funkcji przewodnika religijnego pogan, oraz autor Dziejów Apostolskich w Dz 1,16 ${ }^{29}$. Przewodnik bywa więc często w Nowym Testamencie osobą nieświadomą zgubnej roli, jaką odgrywa. Nie oznacza to jednak jego niewinności, a raczej przynależność do świata duchowych ciemności. Użycia w Dz 1,16 określenia przewodnik w odniesieniu do Judasza nie należy więc raczej rozumieć jako pomniejszenia negatywnej roli Judasza, ale jako przeniesienie jej na inny plan. Jego dramat nie jest ludzkim dramatem wyboru, ale kosmicznym dramatem walki dobra ze złem. Dlatego może nie pojawia się żadna wzmianka o pobudkach jego decyzji, by podjąć rokowania z przywódcami religijnymi w Jerozolimie. Tylko Mt 26,15 wskazuje na materialne motywy stojące za chęcią wydania Jezusa. Zarówno Mk 14,11, jak Łk 22,5 ukazują pieniężną rekompensatę otrzymaną przez Judasza jako wyraz radości ze strony gremium zainteresowanego śmiercią Jezusa. W każdym razie Łk-Dz tworzą obraz Judasza odmienny od tego, jaki znamy z tradycji Markowo-Mateuszowej. Jest to obraz dość spójny, oparty na starszej tradycji (Mk-Mt), ale nie stroniący od modyfikacji. Jest to ważne dla osadzenia we właściwym kontekście relacji o śmierci Judasza w Dziejach Apostolskich.

(Według Łukasza. Nowe spojrzenie na Trzeciq Ewangelię, Poznań 1992, 362): „to, co stanęło naprzeciwko nich [apostołów], to nie była natura ludzka, lecz zasady i moce, władcy ziemscy... ciemności”. Rolę szatana w Nowym Testamencie słusznie określa, z uwzględnieniem Łk 22,3, K. Kościelniak, Zło osobowe w Biblii. Egzegetyczne, historyczne, religioznawcze $i$ kulturowe aspekty demonologii biblijnej, Kraków 2002, 87 (identycznie tenże, Złe duchy w Biblii i Koranie. Wpływ demonologii biblijnej na koraniczne koncepcje szatana w kontekście oddziaływań religii starożytnych, Kraków 1999, 91).

${ }^{26}$ Polibiusz, Dzieje 5,5,15.

${ }^{27}$ Plutarch, Żywot Aleksandra 27.

${ }^{28}$ Pauzaniasz, Wędrówki po Helladzie 2,11,2. Tekst ten odnosi się do opieki Hery nad Falkesem, synem Temenosa, fundatorem świątyni Hery Prodromia w Sykionie. Pozostałe przypadki odnoszą się do przewodników wojskowych.

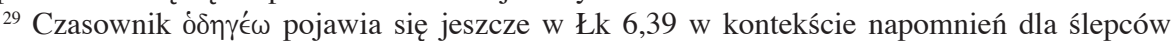
prowadzących innych ślepców. Z drugiej strony J 16,3 mówi o roli Parakleta jako przewodnika, Ap 7,17 - o Baranku. Poza tym w Dz 8,31 czasownik ten jest użyty do określenia wyjaśniania tekstu. 
Dz 1,17 podkreśla związek Judasza z kolegium apostolskim. Składają się na niego dwa zdania proste, między sobą złożone współrzędnie, a wprowadzane przez dotyczący obydwu spójnik ő $\tau$ í mający tu znaczenie przyczynowe. Zanim więc przyjrzymy się, na czym polegała więź między Judaszem a pozostałymi z grona Dwunastu, trzeba zauważyć, że to właśnie ona umożliwiła mu odegranie roli przewodnika. Werset wylicza dwa elementy relacji z pozostałymi apostołami: zaliczenie do ich grona i wspólne posługiwanie. Czasownik $\kappa \alpha \tau \alpha \rho \iota \theta \mu \epsilon ́ \omega$ występuje w Nowym Testamencie tylko tutaj. Septuaginta też posługuje się nim rzadko (tylko trzy razy). Oznacza on „zaliczać do”, „uważać za”. Judasz więc traktowany był przez osoby postronne jako należący do grona apostołów ${ }^{30}$. Co więcej, otrzymał udział w tej samej posłudze ${ }^{31}$. Przeznaczenie i pełnienie przez Judasza posługiwania apostolskiego przypomina jeszcze Dz 1,25. Posługa

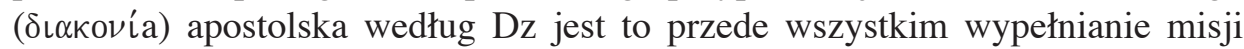
głoszenia (Dz 12,25; 20,24; 21,19). Jest ona przeciwstawiona posłudze w sensie działalności charytatywnej, wykonywanej przez inne osoby (Dz 6,1.4; 11,29). Jest ona również traktowana jako udział $w$ dziedzictwie ( $\kappa \lambda \hat{\rho} \rho \varsigma_{\text {) }}$ (por. Dz 8,21; 26,18). Termin grecki tu użyty pojawia się jeszcze w kontekście uzupełnienia grona Dwunastu w Dz 1,26. Można mieć wątpliwość, czy chodzi tam o przedmiot będący narzędziem praktyki mantycznej (por. Łk 23,34 i par.), czy też o to, że Maciejowi przypadł udział w dziedzictwie apostołów. W każdym razie Judasz miał swój udział w dziedzictwie dwunastu protoplastów nowego Izraela.

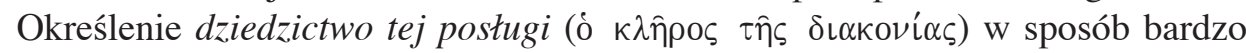
stanowczy podkreśla, że Judasz był pełnoprawnym i autentycznym apostołem. Właśnie dlatego mógł poprowadzić tych, którzy aresztowali Jezusa. Z apostolstwa i udziału w dziedzictwie wynikała możliwość zdrady i udziału w wypełnieniu się Pism dotyczących śmierci Mesjasza.

Badany przez nas werset Dz 1,18 wyróżnia się przez swe dość szczególne słownictwo występujące w relacji o rodzaju śmierci, jaką zmarł Judasz. Zarówno

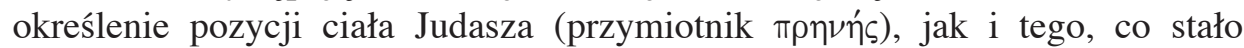
się z tym ciałem (czasownik $\lambda \alpha \kappa \alpha ́ \omega)$, są w całej Biblii Greckiej hapax legomena. Przymiotnik występuje w Dz 1,18 w formie jońskiej, niepoświadczonej w żadnym innym znanym tekście pisanym. Znacznie częstsza jest w lite-

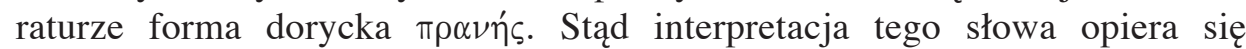
raczej na tradycji przekładowej niż na wiedzy filologicznej ${ }^{32}$. Przymiotnik ten

\footnotetext{
${ }^{30}$ Warto tu zauważyć, że Łk 22,3 określa Judasza rozbudowanym wyrażeniem $\dot{\alpha} \rho \iota \theta \mu o \hat{~} \tau \omega \hat{\nu} \nu \delta \omega ́ \delta \epsilon \kappa \alpha$, co upodabnia język Łk 22,33 do Dz 1,17.

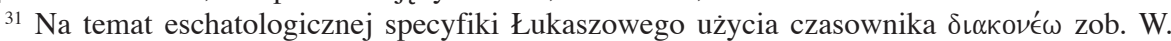
Linke, Maria Magdalena w ewangeliach kanonicznych, Słowo Krzyża 1 (2007) 54-87, zwł. 60.

${ }^{32}$ F. Zorell (Lexicon Graecum Novi Testamenti, Parisiis 1931, 1117) zaopatruje tłumaczenie tego słowa uwagą secundum interpretationem comunem.
} 
opisuje postawę ciała z twarzą do przodu, jak u czworonogów, lub położenie jakiegoś członka ciała jako wysuniętego ku przodowi. Wyraz ten znajduje się w dość skomplikowanych związkach frazeologicznych i gramatycznych. Czasownik $\gamma^{\prime} \iota \nu \mu \alpha \iota$, który pełni funkcję słowa posiłkowego w tym zdaniu, nie daje się łatwo zinterpretować. Zwykle w orzeczeniach imiennych występuje on w znaczeniu „być”, ale z miarami czasu może oznaczać „nadejść” lub „upłynąć”, z rzeczownikami oznaczającymi potomstwo - „rodzić się”, z rzeczownikami oznaczającymi opady atmosferyczne - ,padać”, z rzeczownikami określającymi mienie - „otrzymać”, z rzeczownikami określającymi akt mowy - „mówić”, itd. W swych znaczeniach i funkcjach zastępuje on w Septuagincie hebrajski czasownik ${ }^{33}$. Można więc powiedzieć, że czasownik występuje tu w funkcji posiłkowej, nie mając własnego znaczenia. Opisuje więc raczej stan („znajdował się z głowa naprzód”) niż czynność (,upadł głową naprzód”) ${ }^{34}$.

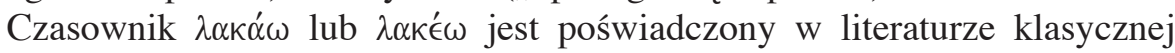
i chrześcijańskiej. Jest to forma dorycka, która upowszechniła się w języku okresu hellenistycznego. Hesychiusz, autor leksykonu z V w. (prawdopodobnie), podaje dla niego znaczenie $\delta\llcorner\alpha \rho \rho \epsilon ́ \omega$ (,przepływać”, „przeciekać przez ściany naczynia”). Przypisuje mu się także znaczenie „,wybuchnąć”, „,rozerwać”35. U Teokryta występuje on w „Czarodziejkach” (w. 24), a więc w części poświęconej opisowi praktyk magicznych. Jego hellenistyczne użycie pozostało zresztą związane z czarami, bowiem słowo to występuje w dokumentach związanych z tą sferą kultury masowej i życia ${ }^{36}$. Tragiczny koniec osoby dotkniętej mocą magiczną miał budzić lęk i obrzydzenie, czyniąc teksty zaklęć i opisy czynności magicznych bardziej przekonującymi. Podobną rolę pełniło w hetyckiej przysiędze wojskowej zaklęcie, które miało dotknąć zdrajców: „niechaj się rozpadnie od choroby i niech skończy śmiercią" ${ }^{37}$.

Publiczny charakter całego wydarzenia podkreśla przymiotnik użyty w zna-

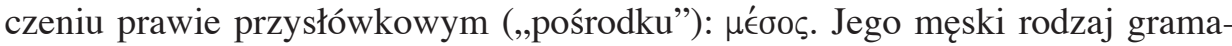
tyczny wskazuje, że odnosi się on do Judasza. Judasz był pośród innych osób, gdy dotknęło go przerażające wydarzenie. Poniósł publicznie konsekwencje swego sprzeniewierzenia się urzędowi apostolskiemu i zajęciu miejsca na czele prześladowców.

Najłatwiej zrozumiałym i najpoprawniejszym gramatycznie jest trzecie wyrażenie opisujące śmierć Judasza, zamykające werset 18. Mowa jest tam o rozla-

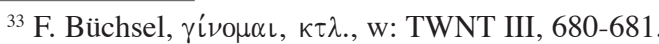

${ }^{34}$ To rzadkie słowo zostało użyte do opowiadania o śmierci herezjarchy Ariusza (Atanazy w Epistula ad Serapionem de morte Arii $[\mathrm{PG} 25,668 \mathrm{c}])$.

${ }^{35}$ H.G. Liddel - R. Scott, A Greek-English Lexicon, Oxford 1996, 1070.

${ }^{36}$ P. Mag. Par I, 3074; P. Leid. V,6.22.

${ }^{37}$ M. Popko, Magia i wróżbiarstwo u Hetytów, Warszawa 1982, 94-95.
} 
niu się wszystkich wnętrzności. W tym tekście $\sigma \pi \lambda \alpha ́ \gamma \chi \nu \alpha$ ma dosłowne znaczenie wnętrzności, które w Nowym Testamencie występuje rzadko ${ }^{38}$. Nowy Testament używa zresztą tego terminu bardzo specyficznie. Przypisuje mu bowiem znaczenie ,miłosierdzie”. Słowo to nie pojawia się w tekstach narracyjnych Nowego Testamentu poza Łk 1,78. Natomiast w dziełach Józefa Flawiusza słowo to oznacza zawsze wnętrzności ${ }^{39}$. Trzykrotnie wspomina on o pęknięciu wnętrzności (Ant. 15,X,3,359; Bell. 1,III,6,81 i 84). We wszystkich trzech tekstach jest mowa o osobach, które można nazwać prześladowcami: w Ant. o Zenodorze, nieuczciwym administratorze majątku Lizaniasza, a w Bell. o Arystobulu, który ponosi karę za ojcobójstwo dokonane na Antygonie. Jeden tekst z Bell. $(5, \mathrm{IX}, 4,385)$ jest dla nas szczególnie ciekawy, ponieważ mowa tam o wypłynięciu wnętrzności

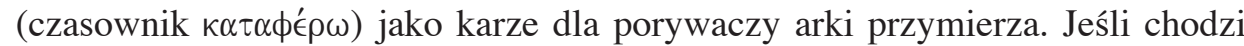
o biblijną wersję tego wydarzenia, to karą dla mieszkańców Aszdod były, według tekstu masoreckiego, wrzody (hemoroidy, por. kere na marginesie $1 \mathrm{Sm} \mathrm{5,3.6.9).}$ Natomiast Septuaginta ma formy dość zaskakujące: „siedziby” (lub „siedzenia”,

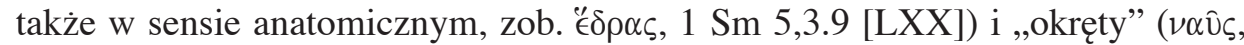

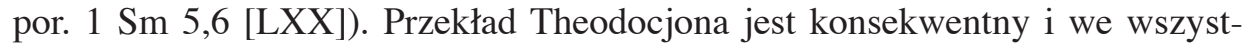
kich trzech miejscach ma słowo $€ \delta \rho \alpha \varsigma$. Widać, że opis kary na świętokradców sprawiał, w przeniesieniu na grunt języka i kultury greckiej, pewne trudności. Podobne trudności napotkał też Józef Flawiusz. Posłużył się więc obrazem pękniętych bądź wypływających wnętrzności jako obrazem kary Bożej dla prześladowcy prawdziwej religii i człowieka nieprawego.

Czynność rozlania nigdzie w Biblii Greckiej nie łączy się z wnętrznościami jako dopełnieniem. Inaczej jest z krwią, która w takim związku frazeologicznym pojawia się wielokrotnie w Starym i w Nowym Testamencie. W Starym Testamencie jest to często element liturgiczny związany z tabu, jakim była krew (por. Wj 29,12; Kpł 4,7.18.25.30.34; 8,15; 9,9; 17,13; Pwt 12,16; 15,23 $\mathrm{i}$ in.). Niekiedy wylanie krwi oznacza też zbrodnię (Rdz 9,6; 37,22; Pwt 19,10; $1 \mathrm{Sm} \mathrm{25,31;} 1 \mathrm{Krl}$ 2,31; Ez 16,36; 18,10; 2 Mch 1,8 i in). Nowy Testament używa obydwu tych znaczeń: liturgicznego w Mt 26,28; Mk 14,24; Łk 22,20 i kryminalnego w Mt 23,35; Łk 11,50; Dz 22,20; Rz 3,15; Ap 16,16. Rozlanie krwi Jezusa jako efekt wydania Go znajduje więc swój odpowiednik w rodzaju śmierci, jakim zginął Judasz.

Wzmianka o tym, że Judasz nabył działkę gruntową ( $\chi \omega \rho$ íov), jest własnym materiałem Dz. Jest ona w jakiś sposób związana z informacją o nabyciu pola

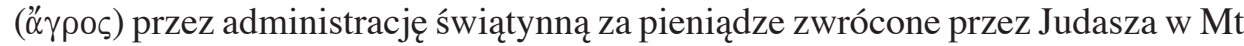

\footnotetext{
${ }^{38}$ H. Köster, $\sigma \pi \lambda \alpha \dot{\gamma} \chi \nu 0 \nu, \kappa \tau \lambda$., w: TWNT VII, 548-559.

${ }^{39}$ Badany rzeczownik występuje u niego 9 razy.
} 
$(27,7-8)^{40}$. Są to jednak informacje niedające się do siebie sprowadzić. Mt 27,8 wskazuje wyraźnie na etiologiczny charakter tego opowiadania ${ }^{41}$. Informacja w Dz 1,18 jest znacznie uboższa, jednak pozostaje ona w zgodzie ze wzmianką Łk 22,5, iż Judasz otrzymał od przywódców jerozolimskich pieniądze (bez wskazania kwoty). Wynagrodzenie to określone jest z kolei w Dz 1,18 jako zapłata nieprawości. To wyrażenie występuje poza Dz 1,18 tylko w 2 P 2,13.15. W Nowym Testamencie podobne konstrukcje z genetiwem $\alpha \delta$ z znaleźć w Łk 16,8.9; Dz 8,23; Rz 6,13; 2 Tes 2,10; Jk 3,16. Spośród pism narracyjnych Nowego Testamentu używają go więc tylko Łk i Dz, w których też znajduje się większość (4 na 7) wyrażeń tego rodzaju. Można uznać ten hebraizm ${ }^{42}$ za Łukaszowy.

Dz 1,19 podają też semicką nazwę owej działki, podczas gdy Mt 27,8 nazwę tę podaje tylko w tłumaczeniu. Jest to zaskakujące, ponieważ to właśnie Mt posługuje się częściej niż Łk-Dz słowami semickimi (najczęściej aramej-skimi).

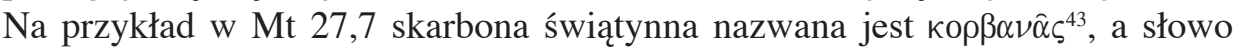

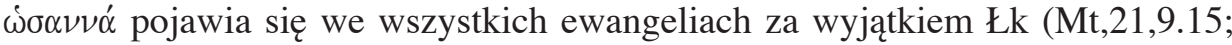
Mk 11,9.10; J 12,13). Łk nie podaje też semickiej wersji psalmu wypowiedzianego przez Jezusa na krzyżu (por. Mt 27,46; Mk 15,34). Z drugiej jednak strony rzeczownik $\mu \alpha \mu \omega \nu \hat{\alpha} \varsigma$ występuje tylko raz w Mt $(6,24)$, a w Łk aż trzy razy $(16,9.11 .13)$. Natomiast Dz poza tym miejscem nie zawierają semityzmów leksykalnych. Można więc podejrzewać, że to właśnie Dz 1,18-19 przekazują pierwotniejszą formę tradycji dotyczącej nazwy owej działki.

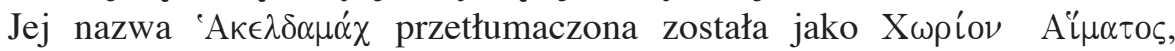

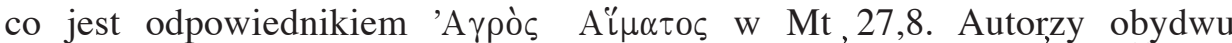
tekstów konsekwentnie tłumaczą słowo aramejskie występowało ono w klasycznym hebrajskim, ale z reguły występuje w aramejskim targumicznym jako odpowiednik słowa hebrajskiego ,pole”, „posiadłość

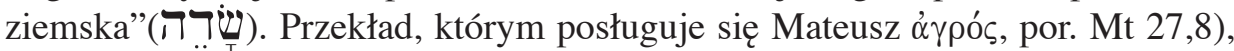

40 L. Desautels uważa, że opowiadanie Mateuszowe może sięgać nawet tradycji przedmateuszowej, zob. tenże, La mort de Judas (Mt 27, 3-10; Ac 1, 15-26), ScEs 38 (1986) 221-239, zwł. 228. M.J.J. Menken uważa, że jest to redakcja Mateuszowa, zob. tenże, The Old Testament Quotation in Matthew 27,9-10. Textual form and Context, Bib 83 (2002) 305-328, zwł. 321.

${ }^{41}$ R.E. Brown, The Death of the Messiah, t. 1, New York 1993, 646-647.

${ }^{42}$ F. Blass - A. Debrunner, Grammatica del greco del Nuovo Testamento (GLNT S3), Brescia $1982,237-238(\S 165)$.

${ }^{43}$ J.A. Fitzmyer, The Aramaic Qorban Inscription from Jebel Hallet et Turi, JBL 78 (1959) 60-65; W.F. Albright - C.S. Mann, Matthew. A New Translation with Introduction and Commentary (AB 26), New York i in. 1971, 341.

${ }^{44}$ M. Jastrow, A Dictionary of the Targumim, the Talmud Babli and Yerushalmi, and the Midrashic Literature, New York 1992, 497. 
jest więc jak najbardziej zgodny z praktyką przekładową targumów. Natomiast

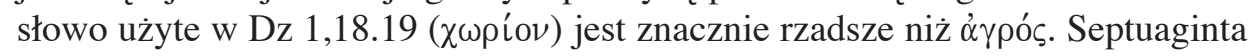
ma tylko jedno miejsce, w którym analizowany termin ma hebrajskie odpowiedniki. W jednym wersecie (1 Krn 27,27) tłumaczy dwa razy słowo hebrajskie (,winnica").

Jak już o tym była mowa, Mateuszowa narracja posługuje się formułą „aż po dziś dzień”, charakterystyczną dla opowiadań etiologicznych. Relacja w Dziejach Apostolskich (Dz 1,19) nie zawiera tej formuły. D. Senior kładł nacisk na rozbieżności w określaniu związku między krwią a kawałkiem gruntu pomiędzy tekstami autorów opowiadających o śmierci Judasza. Sądził on, że o ile w Mt 27,8 chodzi o krew Jezusa, to w Dz 1,18 mowa jest o krwi Judasza,

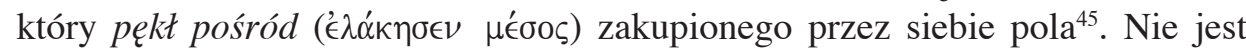
to jednak wniosek przekonujący, bowiem opiera się na nadinterpretacji tekstu Dziejów Apostolskich. Imiesłów $\mu$ éøoৎ należy natomiast odnosić nie tyle do pola (brak związków syntaktycznych), ile raczej do samego Judasza (,pękł w środku”, czego następstwem było wypłynięcie wnętrzności). Można więc założyć, że co do genezy nazwy działki obie relacje Mt i Łk są zgodne. Różnice dotyczą tylko sposobu jej nabycia.

\section{Opowiadania o śmierci Heroda Agryppy I (Dz 12,23; Ant. 19,8,2[346-350])}

Herod Agryppa I (10 r. przed Chr.- 44 r. po Chr. $)^{46}$ ma swoje miejsce w historiografii zarówno Rzymu, jak i Judei. Jego dobre kontakty z najwyżej stojącymi w państwie rzymskim osobami (Tyberiuszem, Kaligulą, Klaudiuszem) spowodowały, że jego osoba była znana dość szeroko poza Palestyną. Udział w konflikcie w Aleksandrii spowodował wzrost jego popularności (co nie oznacza koniecznie dobrej opinii) ${ }^{47}$. Józef Flawiusz miał o nim dobre zdanie, gdyż widział w nim przykład skutecznej i korzystnej dla narodu żydowskiego polityki opartej na założeniu zgodności interesów Żydów i Rzymian ${ }^{48}$. W historyczno-politycznej

${ }^{45}$ D. Senior, The Passion Narrative According to Matthew. A Redactional Study (BETL 39), Leuven 1975, 346-352.

${ }^{46}$ D.C. Braund, Agrippa, w: ABD I, 98-100.

47 J. Mélèze-Modrzejewski, Żydzi nad Nilem Od Ramzesa II do Hadriana (BZ.TNT 3), Kraków 2000, 203-230, zwł. 220-226; J. Maier, Między Starym a Nowym Testamentem (MT 36), Kraków 2002, 197-198; J. Warzecha, Historia dawnego Izraela, Warszawa 2005, 541-546.

${ }^{48}$ S.J.D. Cohen - M. Satlow, Dominacja rzymska. Powstanie żydowskie i zburzenie drugiej świątyni, w: Starożytny Izrael. Od Abrahama do zburzenia świątyni jerozolimskiej przez Rzymian, Warszawa 2007, 385-429, zwł. 400-401. 
wizji Józefa Herod stanowił pozytywny przykład relacji, których całkowitym odwróceniem było powstanie antyrzymskie. Może dlatego żydowski historyk podkreślał jego pobożność, co weszło też do tradycji rabinackiej ${ }^{49}$. Represje skierowane przeciw chrześcijanom, jakie przypisują mu Dzieje Apostolskie (Dz 12,1-4), nie kolidują z tym obrazem, przedstawiają jednak inne oblicze rządów Agryppy I. Motywem podjętych przez niego prześladowań była nie tyle chęć walki z nowym ruchem religijnym, ile raczej chęć przypodobania się faryzeuszom $^{50}$ czy środowiskom kapłańskim ${ }^{51}$.

Dzieje Apostolskie zawierają narrację o śmierci Agryppy I (Dz 12,20-23). Jest to rzadki przypadek, gdy można skonfrontować opowiadanie nowotestamentowe $\mathrm{z}$ relacją Józefa Flawiusza, który także przedstawia ten fakt. O ile jednak autor chrześcijański jest niechętny Agryppie jako prześladowcy chrześcijan, o tyle u Józefa brak takiego nastawienia, a co więcej - historyk chce bronić polityki i osoby tragicznie zmarłego władcy ${ }^{52}$. Śmierć ta w ujęciu Józefa jest następstwem kilkudniowych cierpień. Władca popełnił błąd, nie reagując na głosy pochlebców (Ant. 19,8,2[346]). Nie można wykluczyć interwencji czynnika nadprzyrodzonego, bowiem złowróżbna sowa, której pojawienie się

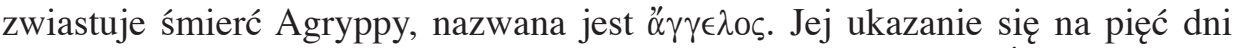
przed śmiercią Agryppy jest zapowiedziane w Ant. 18,6,7(200). Śmierć władcy w relacji Józefa nie jest jednak haniebna, lecz towarzyszy jej szczera żałoba społeczeństwa.

W Dz 12,1 Agryppa został wprowadzony jako Herod król, co jest nawiązaniem do Heroda Wielkiego, prześladowcy Jezusa ${ }^{53}$. Śmierć Agryppy nastąpiła natychmiast po akcie bałwochwalczym i miała charakter odrażający. Został on bowiem strawiony przez robaki ( $\sigma \kappa \omega \lambda \eta \kappa o ́ \beta \rho \omega \tau o \varsigma)$. Ten rzadki termin w Septuagincie nie występuje, w Nowym Testamencie jest hapax legomenon. Jest jednak poświadczony w dziele następcy Arystotelesa, Teofrasta z Eresos (370-287 przed Chr.), o roślinach (De causis plantarum 3,12,8; 4,11,1). Nie można więc uznać go za efekt twórczości leksykograficznej autora Dziejów Apostolskich, natomiast odniesienie go do człowieka jest zabiegiem twórczym. Opowiadanie cechuje się raczej obrazowością niż realizmem. Trudno sobie wyobrazić, że śmierć tego rodzaju nastąpiła tak nagle.

${ }^{49}$ L.I. Levine, Jerusalem. Portrait of the City In the Second Temple Period (538 B.C.E. - 70 C.E.), Philadelphia 2002, 296, przyp. 44.

${ }^{50}$ E. Dąbrowski, Dzieje Apostolskie, 326.

${ }^{51}$ L.I. Levine, Jerusalem. Portrait of the City, 297.

${ }^{52} \mathrm{~K}$. Lake, The Death of Herod Agrippa I, w: The Beginnings of Christianity, red. F.J. FoakesJackson - K. Lake, t. 5, London 1933, 446-452.

${ }^{53}$ L.T. Johnson, The Acts of the Apostles, 210. 
Kara za pychę to motyw, który można wskazać w Ez 28,2nn; Dn 5,20. Jednak nie ma w tych tekstach wzmianki o interwencji anioła. Ten uderza natomiast w nieprzyjaciół Ludu Bożego (2 Krl 19,35, por. Syr 48,21; 1 Mch 7,41). Śmierć Agryppy jest więc raczej charakterystyczna dla wroga tych, których Bóg otacza troską niż dla pysznego władcy. Pycha stanowi jednak istotny element jego upadku.

\section{2 Mch jako wzorzec opowiadań o śmierci prześladowcy}

Żydowska historiografia opierająca się na wzorcach hellenistycznych zna motyw wstrętnej choroby jako kary dla pysznego prześladowcy Żydów. Przykładem tego motywu jest opowiadanie o śmiertelnej chorobie Antiocha IV Epifanesa (panował 175-164 przed Chr.), jakie zawiera 2 Mch 9,1-17. Antioch IV Epifanes był władcą, który podjął próbę ocalenia chylącego się ku upadkowi państwa Seleucydów ${ }^{54}$. Nie mógł pozostać obojętny wobec wewnątrzżydowskich konfliktów, które dotyczyły stosunku do hellenizacji Judei oraz do idei asymilacyjnych ${ }^{55}$. Nie do końca zgodnie z pozabiblijnymi źródłami, historiografia biblijna okresu machabejskiego przedstawia go jako prześladowcę Żydów i głównego odpowiedzialnego za prześladowania wiernych tradycjom judaizmu $^{56}$. Niewiele wiemy o przyczynach jego śmierci poza tym, co mówią 1-2 Mch. Nie dostarczają one jednak spójnych danych, bowiem w 1 Mch 6,16 mowa jest o jego śmierci spowodowanej zgryzotą i smutkiem, a w 2 Mch 1,14-16 mówi się o jego gwałtownej śmierci podczas próby ograbienia świątyni. Opowiadanie w 2 Mch 9,1-17 wydaje się wtórne względem wspomnianych wcześniej. Widzimy bowiem Antiocha IV Epifanesa podczas próby ograbienia świątyni (w. 2), natomiast 1 Mch 6,12 (wyrzuty z powodu traktowania Żydów) przypominają 2 Mch 9,14-17. Styl tego fragmentu, mieszający szczegóły zaczerpnięte z różnych źródeł i rozbudowujący je o poruszające, dydaktyczne

${ }^{54}$ A. Świderkówna, Hellenika. Wizerunek epoki od Aleksandra do Augusta, Warszawa 1995², 249-253.

55 J. Whitehorne, Antiochus IV Epifanes, w: ABD I, 270-271; J. Wolski, Dzieje i upadek imperium Seleucydów, Kraków 1999, 100-101; J.C. VanderKam, Wprowadzenie do wczesnego judaizmu, Warszawa 2006, 30-34.

${ }^{56}$ Zob. M. Marciniak, Hellenistyczna reforma i prześladowanie religijne w Judei za czasów Antiocha IV Epifanesa - przeglqd najważniejszych hipotez, RBL 59 (2006) 245-264. Silny wpływ opowiadań z 1-2 Mch można znaleźć w L.I. Levine, Okres hellenistyczny. Aleksander Wielki. Narodziny i upadek dynastii hasmonejskiej, w: Starożytny Izrael, 337-384, zwł. 346-349. Znacznie bardziej wyważona jest opinia wyrażona w: J.A. Soggin, Storia d'Israele. Dalle origini a Bar Kochbà (BCR 44), Brescia 1984, 431-446 czy J. Warzecha, Historia dawnego Izraela, 447-451. 
elementy, wskazuje na zamiar zbudowania monumentalnej sceny, która ostatecz-nie napiętnuje prześladowcę ${ }^{57}$. Formy cierpienia, jakie dotknęły Antiocha, są skumulowane i nie do końca powiązane ze sobą: najpierw dotyka go

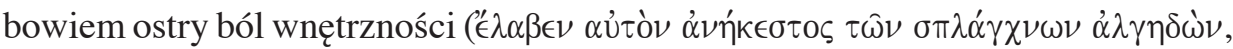
w. 5), następnie spada z wozu, którym jechał, co powoduje znaczne obrażenia

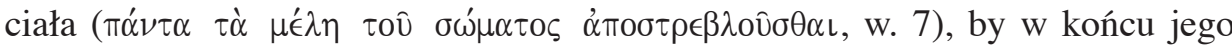
ciało zaczęło gnić (w. 9), co powodowało lęgnięcie się w ciele robactwa ('€́ oû

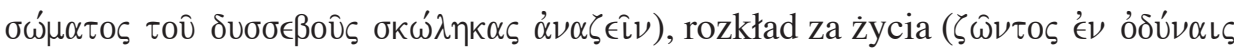

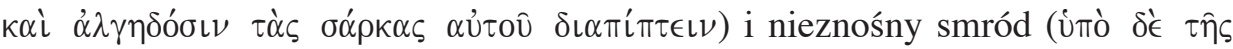

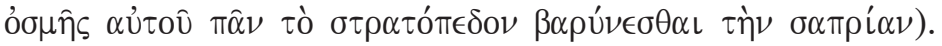

Opowiadanie to zawiera szereg egzotycznych terminów opisujących

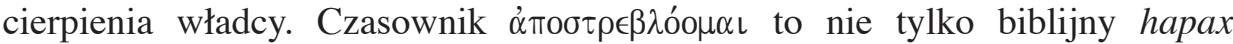
legomenon, ale też neologizm ${ }^{58}$. Przymiotnik $\dot{\alpha} \nu \eta ́ \kappa \epsilon \sigma \tau о \varsigma$ występuje jeszcze tylko w Est 8,12e $\mathrm{e}^{59}$. Rzeczownik $\dot{\alpha} \lambda \gamma \eta \delta \dot{\omega} \nu$ jest specyficzny dla 2 Mch $(6,30 ; 7,12$; 9,5.9), bowiem poza tą księgą znajdujemy w Septuagincie tylko jedno jego

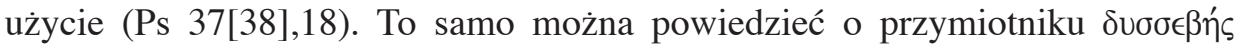
(tylko w 2 Mch: 3,11; 8,14; 9,9; 15,33 i w 3 Mch 3,1) ${ }^{60}$. Rzeczownik $\sigma \alpha \pi \rho i ́ \alpha$ (por. 2 Mch 9,9) stosunkowo częsty jest tylko w septuagintalnej parafrazie Księgi Hioba $(2,9 ; 7,5 ; 8,16 ; 17,14 ; 21,26 ; 25,16)^{61}$. W tym opowiadaniu, które możemy uznać za pierwsze i wzorcowe opowiadanie o śmierci prześladowcy, intencja napiętnowania negatywnego bohatera mija się z realistycznym sposobem przedstawiania końca jego życia. Śmierć przerażająca przez swój odrażający charakter dotyka wnętrzności, związana jest z psuciem się za życia. Jest ona wynikiem bezpośredniej interwencji Boga, który „uderzył” Antiocha (2 Mch 9,5).

\section{4. Łukaszowy portret Judasza jako prześladowcy}

W Dziejach Apostolskich wykorzystany jest pochodzący $\mathrm{z}$ hellenistycznej historiografii biblijnej motyw śmierci prześladowcy. Bardziej dosłownie autor

${ }^{57}$ S. Gądecki, Walka i męczeństwo za wiarę. (2 Księga Machabejska), w: Księgi historyczne Starego Testamentu, cz. 2: Dziejopisarstwo okresu judaistycznego (WMWKB 3), Warszawa 2007, 244-304, zwł. 269-270.

${ }^{58}$ J. Lust - E. Eynikel - K. Hauspie, A Greek-English Lexicon of the Septuagint, t. 1, Stuttgart $1992,56$.

${ }^{59}$ Poza kanonem jeszcze 3 Mch 3,25.

${ }^{60}$ Cała rodzina wyrazów złożonych z przedrostka $\sigma u \nu$ - i wyrazów zbudowanych na rdzeniu $\sigma \epsilon \beta$-, por. J. Lust - E. Eynikel - K. Hauspie, A Greek-English Lexicon, 123.

${ }^{61}$ Poza tym pojawia się w J1 2,20 i PsSal 14,7; 16,14. 
tego dzieła wykorzystał go w opowiadaniu o śmierci Agryppy (Dz 12,20-23). Pewne charakterystyczne elementy znaleźć jednak można także w opowieści o śmierci Judatsza (Dz 1,16-20). Judasz jako przewodnik tych, którzy aresztowali Jezusa, stał na czele prześladowców Pana. Jego śmierć była karą za popełnioną zbrodnię i została przewidziana w planach Bożych objawionych w Biblii Hebrajskiej. Jest ona przedstawiona w sposób niejasny, trudny do wyobrażenia sobie, przy pomocy rzadkiego i specyficznego słownictwa. Ma ona nie tyle odtwarzać przebieg wydarzeń, ile raczej napiętnować Judasza jako prześladowcę. Dobrze odczytał intencję autora tego opowiadania Papiasz ${ }^{62}$, który wzbogaca opowiadanie oparte na Dz 1,16-20 o takie szczegóły jak: opuchlizna, smród, ropne wydzieliny i robaki.

Dzieje Apostolskie nie pretendują więc do przekazania alternatywnej wersji śmierci Judasza, nie wskazują na istnienie innej tradycji historycznej, wpisują raczej wątek Judasza w tendencję wykorzystywania hellenistycznych wzorców stylistycznych ${ }^{63}$. Relacja Dz o śmierci Judasza jest więc spójnym opracowaniem, ujętym w kluczu teologicznym. Jej bohater ukazany jest jako postać historyczna, jednakże autorowi Dz nie zależy na zbieraniu faktów, które go dotyczą. Nie oznacza to też, że nie zna wersji Mateuszowej. Dopracowuje ją raczej, jeśli chodzi o nazwę pola zakupionego za pieniądze pochodzące $\mathrm{z}$ przestępstwa prześladowania Jezusa. Tworzy narrację ujętą w konwencję zrozumiałą dla jego czytelników i nastawioną na ocenę Judasza, który sprzeniewierzył się swemu urzędowi. Miał być uczniem Jezusa, a okazał się przewodnikiem jego prześladowców. Saul z Tarsu prześladował Jezusa w Jego Kościele (Dz 9,4.21; $22,7.8 ; 26,14)$, natomiast Judasz uczynił to wobec Jezusa za Jego ziemskiego, przedpaschalnego życia. Los Pawła nie był jednak naznaczony karą, bowiem ten, przystawszy do apostołów Jezusa, występowat [...] dowodzqc, że Ten [Jezus] jest Mesjaszem (Dz 9,22). W ten sposób los Pawła stanowi odwrotność losu Judasza, który porzucił urząd apostolski, a stanął na czele prześladowców.

${ }^{62}$ E. Norelli, Papia di Hierapolis. Esposizione degli oracoli del Signore. I frammenti (Letture cristiane del primo millennion 36), Milano 2005, 336-350. Tł. pol. w: Apokryfy Nowego Testamentu, t. 2: Apostołowie, cz. 2, red. M. Starowieyski, Kraków 2007, 931-932.

${ }^{63}$ Por. wyniki badań Pietera W. van der Horsta nad Dz 2 i 3-4 w: Hellenistic Parallels to the Acts of the Apostles (2.1-47), JSNT 8 (1985) 49-60 i Hellenistic Parallels to Acts (Chapters 3 and 4), JSNT 11 (1989) 37-46. 


\section{Summary}

Being concerned of Judas has increased with discovery of an apocrypha attributed to him. However, it seems that canonical traditions about him are still not perfectly examinated, especially the one in Acts 1:16-20.

The present article is an attempt of an exegetical analysis of that pericope and indicates its relations with the other narratives about pursuer death, both in Acts itself (12:20-23) as in earlier literature (2Mc 9:1-17). Even in an early apocryfic tradition connected with St. Papius of Hierapolis this direction of Judas' death interpreting appears. 
